\title{
Analisis Pendapatan Petani Ubi Alabio (Dioscorea alata) Di Desa Nelayan Kecamatan Sungai Tabukan Kabupaten Hulu Sungai Utara Propinsi Kalimantan Selatan
}

\section{(The Income Analysis Alabio Yam (Dioscorea alata) Farmers in Nelayan Village Sungai Tabukan District Hulu Sungai Utara Regency South Kalimantan Province)}

\author{
Mahdalena \\ Program Studi Agribisnis, Sekolah Tinggi Ilmu Pertanian Amuntai \\ dalena.stiper@gmail.com
}

\begin{abstract}
ABSTRAK
Pembangunan pertanian ditujukan untuk meningkatkan pendapatan petani dan peran pertanian dalam pembangunan nasional secara keseluruhan. Di antara sektor-sektor ekonomi, pertanian harus tetap menjadi landasan pembangunan daerah kabupaten Hulu Sungai Utara. Potensi sektor pertanian di kabupaten Hulu Sungai Utara meliputi padi dan kacang-kacangan, jagung, kacang tanah, ubi jalar atau ubi alabio yang lebih dominan. Tujuan penelitian ini adalah: (i) mengetahui biaya dan penerimaan petani ubi alabio selama satu kali usahatani berlangsung, (ii) mengetahui bagaimana kontribusi ubi alabio terhadap pendapatan petani selama satu kali usahatani, (iii) mengetahui permasalahan yang dihadapi oleh petani. Penelitian ini telah dilakukan di Desa Nelayan Kecamatan Tabukan Kabupaten Hulu Sungai Utara, dari bulan April - Mei 2009. Sedangkan metode pengumpulan data adalah metode wawancara langsung dengan petani yang dibantu responden sampel menggunakan kuesioner. Di pertanian ubi alabio di Desa Nelayan biaya eksplisit rata-rata Rp 343.702,8, - / usahatani. Pendapatan rata-rata yang diperoleh Rp 2.439.036, 11, - dan pendapatan rata-rata $R p$ 2.095.333,3, dengan kontribusi rata-rata 17,6\%. Pertanian ubi alabio di Desa Nelayan adalah kegiatan sampingan, secara tradisional dibudidayakan dengan skala pekerjaan masih kecil. Harga jual ubi alabio perkilogramnya di Desa Nelayan berkisar antara Rp4.000,00 - Rp7.000,00.
\end{abstract}

Kata kunci: Ubi, alabio, biaya, penerimaan, usahatani.

\begin{abstract}
Agricultural development is aimed at increasing farmers' income and the role of agriculture in overall national development. Among the economic sectors, agriculture must remain the cornerstone of the development of the Hulu Sungai Utara district. The potential of the agricultural sector in Hulu Sungai Utara district includes rice and beans, corn, peanuts, sweet potatoes or sweet potato alabio which are more dominant. The objectives of this study were: ( $i$ ) to find out the cost and acceptance of the alabio yam farmers for one farm, (ii) to find out how the alabio sweet potato contributes to farmers' income during one farm, (iii) to know the problems faced by farmers. This research has been carried out in the Tabukan Sub-District Fishermen Village, Hulu Sungai Utara Regency, from April to May 2009. While the data collection method is a direct interview method with farmers who are assisted by sample respondents using a questionnaire. At the alabio cassava farm in Desa Nelayan the average cost is Rp. 343,702.8, - / farming. The average income earned is Rp 2,439,036, 11, - and the average income is Rp 2,095,333.3, with an average contribution of $17.6 \%$. Alabio yam farming in Desa Nelayan is a side activity, traditionally cultivated with a small scale of work. The selling price of the alabio perilogram in Nelayan Village ranges from Rp. 4,000 to $R$ p. 7,000.
\end{abstract}

Keywords: Yam, alabio, costs, receipts, farming.

\section{PENDAHULUAN}

Pembangunan pertanian ditujukan untuk meningkatkan pendapatan petani dan peran pertanian dalam pembangunan nasional secara keseluruhan. Berbagai kegiatan telah ditempuh pemerintah dalam pembangunan pertanian yang secara garis besar meliputi diversifikasi, intensifikasi, ekstensifikasi dan rehabilitasi. Melalui kegitan-kegiatan tersebut produksi pertanian dapat meningkat secara cepat (Soekartawi, 2005). 
Setelah masa krisis berlalu sektor pertanian telah berhasil lepas dari perangkap spiral pertumbuhan rendah dengan laju pertumbuhan PDB 1,83 persen pertahun, namun permasalahannya sekitar 21,1 juta jiwa penduduk yang bekerja disektor pertanian adalah penduduk miskin dan kurang sejahtera. Oleh karena itu diperlukan kebijakan-kebijakan untuk meningkatkan pendapatan melalui berbagai aspek yang menunjang peningkatan sektor pertanian dan dan nonpertanian ${ }^{3}$.

Diantara sektor-sektor ekonomi, maka pertanian harus tetap menjadi landasan pembangunan regional kabupaten Hulu Sungai Utara. Areal lahan yang luas merupakan suatu modal yang sangat penting bagi perekonomian, khususnya bagi pengembangan pertanian. Selain itu pertanian merupakan sektor yang paling besar dalam sumbangannya terhadap pertumbuhan ekonomi Kabupaten Hulu Sungai Utara. Tahun 2006 sektor pertanian mengalami pertumbuhan yang positif yaitu $7,36 \%$.

Potensi sektor pertanian di kabupaten Hulu Sungai Utara meliputi komoditas padi dan palawija dengan luas tanam dan luas panen yang berbeda. Untuk komoditas padi sawah luas tanam seluas 27.201 hektar namun dipanen hanya seluas 26.560 hektar. Demikian pula tanaman jagung, kacang tanah, ubi jalar atau ubi alabio yang lebih dominan di kabupaten Hulu Sungai Utara dan ubi kayu terdapat selisih antara luas tanam dengan luas panen, sedangkan komoditas lain seperti kacang tanah dan kacang hijau luas tanam sama dengan luas panen.

Selama ini Petani di desa Nelayan mengusahakan ubi alabio hanya sebagai tanaman sampingan selain menanam padi. Tanaman ubi alabio tersebut masih diusahakan secara tradisional sehingga hasil produksinya relatif rendah (belum maksimal), oleh karena itu kontribusi pendapatan ubi alabio juga rendah dan belum cukup untuk memenuhi kebutuhan para petani. Dari uraian latar belakang seperti itulah maka sangat perlu di lakukan penelitian ini.

Tujuan dari penelitian ini adalah : (i) mengetahui biaya dan penerimaan petani ubi alabio selama satu kali usahatani berlangsung, (ii) mengetahui bagaimana kontribusi ubi alabio terhadap pendapatan petani selama satu kali usahatani, (iii) mengetahui permasalahan yang dihadapi oleh petani.

\section{METODE PENELITIAN}

\section{Tempat dan Waktu Penelitian}

Penelitian ini telah dilaksanakan di Desa Nelayan Kecamatan Sungai Tabukan Kabupaten Hulu Sungai Utara. Waktu pelaksanaan penelitian dari bulan April - Mei 2009.

\section{Jenis dan Sumber Data}

Dalam penelitian ini diperlukan data primer dan data skunder. Data primer diperoleh dari wawancara langsung dengan responden dengan menggunakan daftardaftar pertanyaan yang telah disiapkan terlebih dahulu, sedangkan data skunder diperoleh dari data-data instansi terkait melalui dokumen yang tersedia pada instansi yang bersangkutan. Sedangkan metode pengumpulan data adalah metode wawancara langsung terhadap petani contoh sebagai responden yang dibantu dengan menggunakan daftar pertanyaan.

\section{Analisis Data}

Data yang sudah terkumpul, kemudian diolah dengan menggunakan tabulasi dan selanjutnya dianalisis. Analisis meliputi biaya, penerimaan dan pendapatan petani ubi alabio, dengan menggunakan perhitungan berikut :

1. $\mathbf{T C}_{\mathbf{E}}=\mathbf{X}_{\mathrm{Ei}}$. $\mathbf{P X E i}_{\mathbf{X}}$

Dimana :

$\mathrm{TC}_{\mathrm{E}}$ : Biaya ekplisit (Rp per periode)

$\mathrm{X}_{\mathrm{Ei}}$ : Jumlah input / faktor produksi ekplisit ke-i (unit)

$\mathrm{P}_{\mathrm{XEi}}$ : Harga per unit input ekplisit ke-i (Rp per unit)

i $\quad: 1,2,3 \ldots \mathrm{n}$

\section{2. $\mathrm{Du}=\frac{\mathrm{Na}-\mathrm{Ns}}{\mathrm{Up}} \times \mathrm{Le}$ Up}

Dimana :

$\mathrm{Du}$ : Besarnya nilai penysutan barang modal tetap yang dipergunakan untuk usaha tertentu selama masa produksi (bulan) 
$\mathrm{Na}$ : Besarnya nilai awal barang modal tetap yang sama dengan harga pengadadaan atau harga pembeliannya (Rp)

Ns : Besarnya nilai sisa dari barang modal tetap yang ditaksir sama dengan harga pada saat tidak dipergunakan lagi ( $\mathrm{Rp})$

Up : Umur penggunaan barang modal tetap bersangkutan (tahun)

Le : Lamanya penggunaan efektif barang pada suatu usaha tertentu (Tahun)

3. $\mathbf{T R}_{\mathbf{Y}}=\mathbf{Y}$. PY

Dimana :

TRY : Penerimaan Total

Y : Produksi $(\mathrm{Kg})$ per periode

$\mathrm{P}_{\mathrm{Y}}$ : Harga produksi (price) $\mathrm{Rp} / \mathrm{Kg}$

4. $F 1=T R-T C_{E}$

Dimana :

F1 : Pendapatan (Rp)

TR : Penerimaan (Rp)
$\mathrm{TC}_{\mathrm{E}} \quad$ : Biaya Ekplisit (Rp per periode)

5. $\mathrm{KU}=$ Pendapatan Ubi Alabio $\times 100 \%$ Total Pendapatan Petani

\section{HASIL DAN PEMBAHASAN}

\section{Biaya Eksplisit}

Biaya eksplisit adalah semua biaya yang secara nyata dikeluarkan oleh petani dalam penyelenggaraan usahataninya. Biaya yang dibeli dalam pelaksanaan usahatani ubi alabio adalah biaya penyusutan alat dan perlengkapan, biaya perlengkapan yang habis sekali pakai dalam satu periode tanam, biaya bibit, biaya pupuk dan biaya obatobatan. Jenis biaya tersebut dikelompokkan kedalam biaya eksplisit. Rincian biaya eksplisit dapat dilihat pada Tabel 1 berikut.

Tabel 1. Biaya eksplisit rata-rata pada usahatani ubi alabio di Desa Nelayan

\begin{tabular}{clcc}
\hline No & \multicolumn{1}{c}{ Biaya Eksplisit } & Jumlah Biaya (Rp) & Persentase (\%) \\
\hline 1 & Biaya Penyusutan Alat dan Perlengkapan & $10.226,5$ & 2,98 \\
2 & Biaya Perlengkapan yang Habis Sekali & $137.698,8$ & 40,06 \\
& Pakai dalam Satu periode Tanam & & \\
3 & Biaya Bibit & $155.602,0$ & 45,27 \\
4 & Biaya Pupuk & $23.962,5$ & 6,97 \\
5 & Biaya Obat-obatan & $16.213,0$ & 4,72 \\
\hline \multicolumn{2}{c}{ Jumlah } & $343.702,8$ & 100,00 \\
\hline
\end{tabular}

Biaya Penyusutan Alat dan Perlengkapan

Di Desa Nelayan petani responden dalam mengusahakan tanaman ubi alabio menggunakan alat dan perlengkapan seperti cangkul, parang, linggis dan karung. Alat dan perlengkapan yang digunakan dapat dipakai beberapa kali periode tanam atau proses produksi, maka biaya yang diperhitungkan adalah nilai penyusutan. Perhitungan biaya penyusutan alat dan perlengkapan ini berdasarkan lamanya pemakaian alat dan perlengkapan tersebut

Besarnya biaya rata-rata penyusutan alat dan perlengkapan yang dikeluarkan petani responden dapat dilihat pada Tabel 2 berikut.

Tabel 2. Rata-rata penggunaan dan biaya rata-rata penyusutan alat dan perlengkapan pada usahatani ubi alabio di Desa Nelayan

\begin{tabular}{clcc}
\hline No & Jenis Alat dan Perlengkapan & Jumlah (buah) & Biaya (Rp/buah) \\
\hline 1 & Cangkul & 1,4 & $2.791,0$ \\
2 & Parang & 1,3 & $1.333,7$ \\
3 & Linggis & 1,4 & $1.011,4$ \\
4 & Karung & 8,3 & $5.090,4$ \\
\hline & Jumlah & 12,4 & $10.226,5$ \\
\hline
\end{tabular}

Perlengkapan yang habis sekali pakai dalam satu periode tanam 
Biaya perlengkapan yang habis sekali pakai dalam satu periode tanam dalam usahatani ubi alabio adalah ajir dan tali.

Ajir digunakan petani sebagai tempat merambatnya tanaman ubi alabio dan tali untuk mengikatbatang tanaman pada ajir. Ajir ditanam langsung bersamaan dengan penanaman bibit. Ajir yang digunakan petani di Desa Nelayan biasa dari bambu atau kayukayu dahan yang panjangnya kurang lebih 2 meter.

Biaya rata-rata penggunaan perlengkapan yang habis sekali pakai untuk usahatani ubi alabio di Desa Nelayan adalah Rp 137.698,8,-/usahatani.

\section{Biaya bibit}

Pengadaan bibit pada usahatani terbagi dalam dua kemungkinan, bisa dibeli dan bisa juga menggunakan sisa tanaman terdahulu yang sudah disortir untuk menjadi bibit. Apabila bibit itu dibeli perhitungannya termasuk dalam biaya ekplisit dan apabila bibit itu dari sisa tanaman terdahu maka bibit merupakan biaya implisit. Rata-rata biaya bibit yang dikeluarkan petani responden ubi alabio di Desa Nelayan sebesar Rp 155.602,-/usahatani.

\section{Biaya pupuk}

Tabel 3. Penerimaan rata-rata petani ubi alabio di Desa Nelayan

\begin{tabular}{cccc}
\hline No & Produksi Rata-rata $(\mathrm{Kg})$ & Harga Rata-rata $(\mathrm{Rp})$ & Penerimaan $(\mathrm{Rp})$ \\
\hline 1 & 400,36 & 5.880 & $2.439 .036,11$ \\
\hline
\end{tabular}

Rata jumlah produksi ubi alabio adalah 400,36 kg/usahatani dan rata-rata harga jual adalah Rp 5.880,-/kg/usahatani. Dari perhitungan diperoleh penerimaan pada petani responden adalah sebesar $\mathrm{Rp}$ 2.439.036,-/usahatani.

\section{Pendapatan dan Kontribusinya}

Dalam penyelenggaraan usahatani ubi alabio di Desa Nelayan kecamatan Sungai Tabukan petani ubi alabio menggunakan pupuk Urea, KCL dan TSP untuk membantu pertumbuhan tanaman ubi alabio agar bisa menghasilkan produktivitas yang maksimal. Rata-rata biaya pupuk yang dikeluarkan petani ubi alabio di Desa Nelayan adalah Rp 23.962,5,-/usahatani.

\section{Biaya obat-obatan}

Biasanya tanaman ubi alabio yang baru tumbuh atau baru berkecambah mudah diserang ulat, sehingga petani akan membasminya dengan obat ulat baik yang dikemas dalam kaleng atau dalam bungkusan. Biaya rata-rata pengadaan obatobatan dalam usahatani ubi alabio di Desa Nelayan adalah Rp16.213,-/usahatani.

\section{Penerimaan}

Penerimaan usahatani adalah besarnya hasil produksi dari usahatani dikalikan dengan harga yang berlaku ditingkat petani. Penerimaan usahatani pada dasarnya merupakan nilai dan hasil produksi atau output fisik yang diperoleh dari satu cabang atau bebrapa cabang usahatani yang diusahakan dalam usaha-usahatani. Penerimaan rata-rata petani ubi alabio di Desa Nelayan dapat dilihat pada Tabel 3. 
Tabel 4. Pendapatan rata-rata petani ubi alabio di Desa Nelayan

\begin{tabular}{cccc}
\hline No & Penerimaan Rata-rata $(\mathrm{Rp})$ & Biaya Eksplisit Rata-rata $(\mathrm{Rp})$ & Pendapatan $(\mathrm{Rp})$ \\
\hline 1 & $2.439 .036,11$ & $343.702,8$ & $2.095 .333,3$ \\
\hline
\end{tabular}

Tabel 5. Rata-rata pendapatan ubi alabio dan non ubi alabio di Desa Nelayan

\begin{tabular}{cccc}
\hline No & Uraian Pendapatan & Jumlah Pendapatan (Rp) & Persentase (\%) \\
\hline 1 & Pendapatan Ubi Alabio & $2.095 .333,3$ & 17,62 \\
2 & Pendapatan Non Ubi Alabio & $9.795 .349,1$ & 82,38 \\
\hline & Jumlah & $11.890 .682,4$ & 100,00 \\
\hline
\end{tabular}

Kontribusi rata-rata pendapatan petani ubi alabio dapat dilihat pada Tabel 6

Tabel 6. Kontribusi rata-rata pendapatan petani ubi alabio di Desa Nelayan .

\begin{tabular}{ccccc}
\hline No & $\begin{array}{c}\text { Pendapatan ubi } \\
\text { Alabio (Rp) }\end{array}$ & $\begin{array}{c}\text { Pendapatan nonubi } \\
\text { Alabio (Rp) }\end{array}$ & Total pendapatan (Rp) & Kontribusi (\%) \\
\hline 1 & $2.095 .333,3$ & $9.795 .349,1$ & $11.890 .682,4$ & 17,62 \\
\hline
\end{tabular}

Kontribusi rata-rata pendapatan ubi alabio terhadap pendapatan total petani responden hanya $17,62 \%$ dari total pendapatan petani, karena usahatani ubi alabio hanya merupakan usaha sampingan petani responden. Sehingga persentasenya lebih kecil dibandingkan dengan pendapatan non ubi alabio.

\section{Permasalahan Usahatani Ubi Alabio}

Permasalahan yang dihadapi petani ubi alabio di Desa Nelayan diantaranya sebagai berikut:

1. Tanaman ubi alabio masih diusahakan secara tradisional sehingga hasil produksinya relatif rendah (belum maksimal), oleh karena itu kontribusi pendapatan ubi alabio juga rendah dan belum cukup untuk memenuhi kebutuhan para petani.

2. Skala usaha yang dilakukan masih kecil dan belum ada kiat pemasaran yang lebih luas.

\section{KESIMPULAN}

Jumlah biaya eksplisit rata-rata $\mathrm{Rp}$ 343.702,8,-/usahatani. Adapun penerimaan rata-rata yang diperoleh $\mathrm{Rp} 2.439 .036,11$,dan pendapatan rata-rata $\mathrm{Rp} 2.095 .333,3,-$ dengan kontribusi rata-rata $17,6 \%$. Usahatani ubi alabio di Desa Nelayan ini merupakan usaha sampingan, diusahakan secara tradisional dan skala usaha yang dilakukan masih kecil. Harga jual ubi alabio di desa Nelayan perkilogramnya berkisar antara Rp 4.000,- sampai dengan Rp 7.000,-.

\section{DAFTAR PUSTAKA}

BPS Kabupaten Hulu Sungai Utara. 2007. Kabupaten Hulu Sungai Utara Dalam Angka Tahun 2017. Amuntai

Soekartawi. 2005. Agribisnis Teori dan Aplikasinya. PT Raja Grafindo Persada. 